\title{
A bioassay approach to seasonal variation in the nutritional value of sediment
}

\author{
I.-Jiunn Cheng*, Jeffrey S. Levinton, Michael McCartney, Daniel Martinez, \\ Marc J. Weissburg **
}

Department of Ecology and Evolution, State University of New York, Stony Brook, New York 11794, USA

\begin{abstract}
Smaller surface deposit feeding macroinvertebrates probably rely on both microbial and non-living sources of organic matter, but only scant evidence supports the hypothesis that food is limiting to natural populations. Summer declines in deposit feeding populations have been ascribed to food limitation and to the seasonal influx of predators. We used a bioassay approach to test the following hypotheses: (1) Sediment supports more population growth in the spring and early summer, relative to the late summer and fall. (2) The nutritive value of sediment declines from spring to early fall, and absorption therefore should decrease. Laboratory tests using the common deposit feeding oligochaete Paranais litoralis partially support both hypotheses. Population growth studies of spring and summer sediment show a relatively nutritionally enriched surface sediment layer, suggesting that the sediment is recharged in the late fall and winter, either by particulate organic matter deposition or microbial transformation of previously unabsorbable material. High summer temperature contributes to the negative effect of poor sediment quality. In Flax Pond, Long Island, New York, field studies show summer declines of several species of deposit feeding invertebrates, but caging studies demonstrate that predation is not a likely cause of the crashes, which proceed at similar rates inside and outside of cages.
\end{abstract}

\section{INTRODUCTION}

In the last few years, our changing understanding of deposit feeding invertebrates has led to ever more complex models of nutrition (Lopez \& Levinton 1987, Levinton 1989). Previous models often suggested that microbial sources constituted the majority of deposit feeder nutrition (Newell 1965, Fenchel 1970, Hargrave 1970, Yingst 1976). The majority of the evidence rested on the efficient assimilation of microbial food sources, relative to particulate organic matter (POM), which was believed to be usually refractory (e.g. Harrison \& Mann 1975). Field and laboratory evidence suggests that some deposit feeders rely on surface diatoms and these are the main limiting resource for some intertidal

\section{Present addresses:}

- Institute of Marine Biology, National Taiwan Ocean University, Keelung 20224, Republic of China

- Dept of Biology, Georgia State University, PO Box 4010, Atlanta, Georgia 30302, USA surface-grazing gastropods (Fenchel \& Kofoed 1976. Levinton \& Bianchi 1981, Juniper 1987a, b, Morrisey 1988).

This simple model has proven inadequate in explaining deposit feeder nutrition. For many species, microbial sources, especially bacteria, are inadequate to account for metabolic requirements (Tunnicliffe \& Risk 1977, Cammen 1980, Juniper 1987a). Furthermore, in many shallow water environments where most of the organic matter of sediment in salt marsh flats may derive from the decomposition of seagrasses (e.g. Peterson et al. 1986) and perhaps seaweeds, and may be relatively indigestible, it constitutes the overwhelming majority of the organic matter ingested by deposit feeders (Levinton \& Stewart 1988, Cammen 1989, Mayer 1989, Rice \& Rhoads 1989). Thus a relatively low absorption efficiency on this large source may yield as much or even more nutritive return than living microbial material (Cammen 1980, Levinton 1980). In some cases, it can be shown that the decomposition of sedimentary protein yields a $\mathrm{C}: \mathrm{N}$ that 
mimics nutritionally rich living food sources (Carey \& Mayer 1990). Some direct evidence exists for assimilation of non-living detritus (George 1964, Lopez \& Crenshaw 1982, Lopez \& Cheng 1983, Kemp 1986) and detrital additions can stimulate deposit feeder growth in the laboratory (Tenore 1977, Levinton \& Stewart 1988). Given the large storehouse of organic matter in sediment it is not clear that intertidal surface deposit feeders other than diatom feeders (e.g. Pace et al. 1979, Levinton \& Bianchi 1981, Morrisey 1987) might be food limited. Despite the abundance of organic matter, available nitrogen may strongly limit deposit feeder growth (Rice \& Rhoads 1989).

Thus far, studies of digestion suggest that food quality may be strongly limiting to deposit feeders. Deposit feeding invertebrates process a large amount of sediment, amounting to many body weights per day (Lopez \& Levinton 1987). From this, they extract a small amount and the typical movement of a plug of sediment through the gut (Jumars \& Penry 1989) requires an optimal combination of exposure time to digestive enzymes and throughput of total sediment (Taghon 1981, Penry \& Jumars 1987, Kofoed et al. 1989). Some deposit feeders employ a variety of diverticular structures, which complicates digestion theory (Kofoed et al. 1989, Penry \& Jumars 1990).

At the population level, there are other reasons to suspect that food limitation is not always the principal factor regulating production of deposit feeders. Predation is a well known source of strong population regulation of macrofauna and meiofauna on tidal mudflats and tidal creeks (e.g. Schneider 1978, Bell \& Coull 1978, Wiltse et al. 1984, Reise 1985, Smith \& Coull 1987). Competition for space might also limit successful larval recruitment (Woodin 1974, 1976) and interference with mobile resident deposit feeders might also regulate density (Levinton 1977, 1979, Peterson \& Andre 1980, Levinton et al. 1985).

In temperate environments, temperature may interact with food as a limiting factor. In the spring, the deposition of phytoplankton detritus is a major source of food for the benthos (Elmgren 1984, Christensen \& Kanneworf 1985, Marsh \& Tenore 1990). As summer temperatures increase, animals may not be able to acclimate completely and an energy deficit may develop, since higher metabolic costs may be incurred (Bayne et al. 1976, Levinton 1983, 1989, Lonsdale \& Levinton 1985, Marsh \& Tenore 1990). Microbial degradation and animal absorption might also reduce the nutritive value of sediment as the spring and summer season progresses (Tenore et al. 1982, Levinton 1989). Thus late summer and fall may be limiting periods, owing to a long period of degradation of digestible organic matter, combined with the negative effects of high temperature. While assessments of the organic matter in the sediment suggest that available nitrogen may be strongly limiting to deposit feeders (e.g. Rice 1982, Rice \& Rhoads 1989) and fall detritus has been shown to be nutritionally depauperate in Chesapeake Bay (Marsh et al. 1989) we know of no case where the sediment itself has been examined to find out whether significant changes occur seasonally in the sediment's ability to support somatic growth of deposit feeders.

We employ the following model: Winter deposition of organic matter or some other process increases the nutritional value of the sediment, which is followed by a decline owing to feeding, decomposition, microbial activity, and high temperature. If the sediment is becoming more nutritionally depauperate as the season progresses, and if the sediment is food-limiting to the deposit feeding population, then secondary production should decline and the ability of a deposit feeder to derive nutrition from the sediment should also decrease.

It is difficult to test this model in the field, owing to the presence of various confounding factors. We employed cages to examine the importance of predation in summer declines of macrobenthos, but we took a laboratory bioassay approach in order to study seasonal changes in the nutritional value of sediment and the potential for food limitation. Sediment collected over a period of 2 yr was subjected to ultracold freezer storage to prevent decomposition, and offered to deposit feeders to see whether population growth and organic matter absorption differed when animals from the same laboratory culture were exposed under otherwise similar conditions to the different sediments. The population growth bioassay reflects the nutritional value of sediment, assuming that more growth and reproduction implies greater nutritional content. By contrast, organic matter retention gives us an estimate of the ability of an animal to extract carbon from the sediment, but we cannot be assured that this extraction has nutritional value. We chose the common salt marsh mudflat oligochaete Paranais litoralis as our bioassay species, since it was a dominant form in our seasonal surveys and it conveniently reproduces asexually by a form of fission and responds rapidly to nutritionally different conditions and temperatures (Levinton \& Stewart 1982, 1988)

\section{MATERIALS AND METHODS}

Field site and collections. Animals and sediments were collected from a mid-intertidal field site on a broad mudflat at Flax Pond, Long Island, near the village of Old Field, New York, USA (described in Levinton \& Bianchi 1981). This has a low-relief muddy sand, with 10 to $15 \%$ silt-clay. 
From February 1989 to January 1991 we sampled, usually every $2 \mathrm{mo}$, for sediment properties, macroinvertebrate abundance, and microbial abundance. Cores of $3.5 \mathrm{~cm}$ diameter were collected $(\mathrm{n}=20)$ and sieved through a $0.5 \mathrm{~mm}$ mesh. Most cores were $8 \mathrm{~cm}$ deep and we counted only the most common invertebrates, the polychaete Streblospio benedicti, the gastropod Hydrobia truncata (= totteni), and the oligochaete Paranais litoralis. For some samples we subdivided the sediment cores into $1 \mathrm{~cm}$ depth intervals to establish the depth occurrences of these invertebrates. Preliminary collections showed that nearly all species mentioned above occurred in the top $1 \mathrm{~cm}$. Bacteria were counted using a modified acridine orange epifluorescence technique (Hobbie et al. 1977, Levinton \& Bianchi 1981). Samples for bacteria were taken from plastic syringes, $0.9 \mathrm{~cm}$ in diameter by $1 \mathrm{~cm}$ deep. Diatom samples were taken using soda straw cores, $0.6 \mathrm{~cm}$ in diameter, and were counted with the aid of epifluorescence, without staining.

The biomass of the sea lettuce Ulva rotundata was estimated for 1 yr (1984) by collecting samples by excavating all visible seaweed within a square area of $1 \mathrm{~m}^{2}$ (3 replicates randomly chosen). Collections were made at the level of mean high tide, approximate midtide level, mean low tide level, and low water spring level. Data presented are the mean of 3 replicates. In the same year, at the time of low tide (usually at midday) we measured in the mid-intertidal site air temperature, temperature in the upper 3 to $5 \mathrm{~mm}$ of the sediment, and temperature $5 \mathrm{~cm}$ below the sedimentwater interface, by means of a glass-encased mercury thermometer.

Field predation experiment. To estimate the effects of predation on the dominant macrobenthic invertebrates at Flax Pond, we used a design described by Wiltse et al. (1984). Two cages $1 \times 0.5 \times 0.5 \mathrm{~m}$ high were constructed using wood frames with sides and tops of $4 \mathrm{~mm}$ plastic mesh, and were driven into the sediment so that the mesh extended $10 \mathrm{~cm}$ below the sedimentwater interface. The cages were separated by ca $10 \mathrm{~m}$. On June 21, July 1, July 21, and August 10, 1990, 5 replicate cores $(6.7 \mathrm{~cm}$ in diameter, $5 \mathrm{~cm}$ deep) were collected within and just outside each cage to assess abundance in sediments exposed to and protected from putative predators, such as fish and crabs. We counted the most common invertebrates: the bivalve Gemma gemma, the polychaete Streblospio benedicti, the gastropod Hydrobia truncata (= totteni), and the oligochaete Paranais litoralis.

Laboratory assays of population growth. We test the specific null hypothesis that there are no seasonal differences in the nutritive value of sediment, so deposit feeders will exhibit no differences in population growth. We used the naid oligochaete Paranais litoralis to assess population responses to sediments collected in different seasons and to sediments collected at different levels below the sediment-water interface. $P$. litoralis grows by naid paratomy, an asexual form of reproduction involving additions of segments, and budding off of a daughter individual. This form of growth makes this species ideal for laboratory growth studies (see Levinton \& Stewart 1982, 1988). For the entire bimonthly sample series we collected mud less than $5 \mathrm{~mm}$ below the sediment-water interface and froze it at $-80^{\circ} \mathrm{C}$. In March and July 1989, however, we also collected sediment cores and subdivided frozen sections into depth zones of $0-1,1-2,2-3$, and $3-4 \mathrm{~cm}$ below the sediment water interface. These sections were also stored at $-80^{\circ} \mathrm{C}$.

There are 2 alternative possible experimental strategies in our study. We could expose animals to sediment immediately after it is collected, using animals from a stock culture. This has the disadvantage of strong differences in physiological state of the bioassay animal, depending upon food source, nutritional history, and degree of senescence, all of which vary significantly in Paranais litoralis (Levinton \& Stewart 1982, D. Martinez unpubl.). Instead, we chose to freeze sediments at $-80^{\circ} \mathrm{C}$ and store them, exposing animals from the same culture to the different sediments. This latter approach has the disadvantage of possible decomposition, even under ultracold storage. We felt however that the latter approach was preferable, owing to our experience with strong heterogeneity of animal response, when a stock culture was sampled at different times. Analyses of organic carbon, organic nitrogen, protein (Mayer et al. 1986), and various chemical extractions (methods of Cheng \& Lopez 1991) showed no monotonic trends suggestive of extensive degradation.

In the Paranais litoralis population bioassay experiments, we used population size, rather than biomass, as a measure of response. While biomass would be preferable, counts are more convenient. Levinton \& Stewart (1988), moreover, showed that body weight did not vary significantly as a function of nutritional state during the increase part of a $P$. litoralis population cycle. Body weight is inversely related to temperature (Levinton \& Stewart 1988) and a survey using biomass would therefore only magnify the differences in the temperature by sediment experiments reported below.

The depth-response experiment was performed as follows. March and July 1989 sediment was tested in June and in September 1989, respectively. For each experiment, sediment was defrosted and used immediately. Cores ( 3 from the March samples and 4 from July) were sliced and frozen at the time of sampling at depth intervals of $0-1,1-2$, and $2-3 \mathrm{~cm}$. Before the experiment, the slices were defrosted and then mixed into slurries with ca $25 \mathrm{ml}$ seawater, which were then 
aerated for $24 \mathrm{~h}$. The sediment $(1 \mathrm{ml})$ was allowed to settle in $3 \mathrm{~cm}$ circular glass dishes and 10 Paranais litoralis individuals were introduced. Weekly counts of worms in the dishes were then made by removing animals and sediment, and returning both to the dish. Water was changed every $2 \mathrm{~d}$. Counts were performed until populations in all treatments disappeared completely. As in previous experiments (Levinton \& Stewart 1988), P. litoralis populations usually go through a population increase, with a subsequent decline to extinction. Continuing cycles, as have been observed in laboratory capitellid polychaete populations (Chesney \& Tenore 1985), are not seen in $P$. litoralis at the experimental temperatures we employed. Unfortunately, the experiments for the 2 sediment sources were done at different times, so only the relative results among the sediments depths are comparable. In our past experience (Levinton \& Stewart unpubl.), different cultures of $P$. Iitoralis often yield different population responses.

The seasonal response experiment was performed on a series of samples from the spring-fall of 1989 and 1990, respectively. Sediment from the top $5 \mathrm{~mm}$ was collected every 2 mo and frozen at $-80^{\circ} \mathrm{C}$. Dishes of sediment $(8.5 \mathrm{~cm}$ diameter, $0.5 \mathrm{~cm}$ depth) were placed randomly in a recirculating seawater system aquarium (as in Levinton \& Bianchi 1981 ) at $18^{\circ} \mathrm{C}$. We added 10 worms initially to each dish (4 replicates for each bimonthly sediment sample); after $24 \mathrm{~d}$ the sediment from each dish was sieved and worms were counted. All worms were taken randomly from the same culture. Treatments were randomized spatially, and 2 replicate dishes for each month were placed in 2 tanks (4 replicates total). Counts of limited trays were used to monitor population growth so the sampling date would represent a time of maximum rate of population increase. In all of our experiments, Paranais litoralis undergo a characteristic population increase and decline cycle (Levinton \& Stewart 1982). The 24 d assay would be invalid if the pattern of the increase and decline differed as a function of nutritional state, but Levinton \& Stewart (1988) demonstrated that different food qualities change the initial slope of population increase and the size of the population peak, but not the time of the population peak. In experiments reported here the number of days until peak and crash may change, but usually the time of peak and final demise is consistent among treatments (e.g. see Figs. $7 \&$ 9), which validates a single sampling time for comparison.

The temperature $\times$ seasonal response experiment was performed on sediments collected in May and September 1990. The objective of the experiment was to see if temperature or temperature $x$ season effects were important in regulating population growth. As in the seasonal response experiment, sediment from the upper
$5 \mathrm{~mm}$ of the sediment column was used, and 10 worms were added initially to each dish. Dishes were arrayed in 4 aquaria ( 2 for each temperature), maintained at 18 or $25^{\circ} \mathrm{C}$, and collected periodically, sieved, and assessed for worm abundance 4 replicates total for each treatment). From previously collected data, both water and sediments commonly exceed $25^{\circ} \mathrm{C}$ at the field site. This experiment was continued until populations had increased and crashed in all 4 conditions (May or September sediment, high or low temperature).

Organic matter retention. We used Paranais litoralis to assess organic matter retention. Sediment slurries were labeled with ${ }^{14} \mathrm{C}$-formaldehyde, which labels nonliving organic matter and living organic matter to an unspecified degree (Lopez \& Cheng 1983). Preliminary experiments using sediment that was labeled with both ${ }^{14} \mathrm{C}$-formaldehyde and with ${ }^{51} \mathrm{Cr}$ (as suggested by Calow \& Fletcher 1972) showed no retention of chromium, so we continued experiments using only ${ }^{14} \mathrm{C}$-formaldehyde. We added $14 \mu \mathrm{Ci}{ }^{14} \mathrm{C}$ to a $0.8 \mathrm{ml}$ slurry, which was incubated for $8 \mathrm{~d}$. The mixture was then rinsed with seawater 3 times to remove $\mathrm{NaCl}$ and unincorporated label. On average, only about $43 \%{ }^{14} \mathrm{C}$-formaldehyde was incorporated into the sediment. The sediment was then sprinkled with orange fluorescent particles, in order to view food entering the gut (which was transparent). The feeding experiment was performed in small glass wells with 10 worms. Worms were allowed to feed about 10 to $20 \mathrm{~min}$ on a mixture of labeled sediment and fluorescent dye particles. The animals were then transferred into unlabeled natural sediment and allowed to feed until all fluorescent particles were egested. Then the worms were removed, frozen, and analyzed for ingested ${ }^{14} \mathrm{C}$. Fecal pellets were also collected and analyzed for egested ${ }^{16} \mathrm{C}$. All counts were done using an LKB model 1217 scintillation counter. Retention efficiency (\%) was calculated as $\left[{ }^{14} \mathrm{C}\right.$-ingested/ $\left({ }^{14} \mathrm{C}\right.$-ingested $+{ }^{14} \mathrm{C}$-feces $\left.)\right] \times 100$.

\section{RESULTS}

\section{Field surveys and experiments}

All 3 principal surface deposit feeding species increased in abundance in late spring, but then declined by the end of September (Fig. 1). For Hydrobia truncata the summer increase represents recruitment from juveniles emerging from eggs deposited on adults. Streblospio benedicti recruits from short-lived planktonic larvae, but it is not clear whether these larvae originate from the local mudflat (see Levin 1986). Paranais litoralis seems to reproduce only asexually in Flax Pond, so population growth is most likely explained only by expansion of the local population. The cycle of late spring 


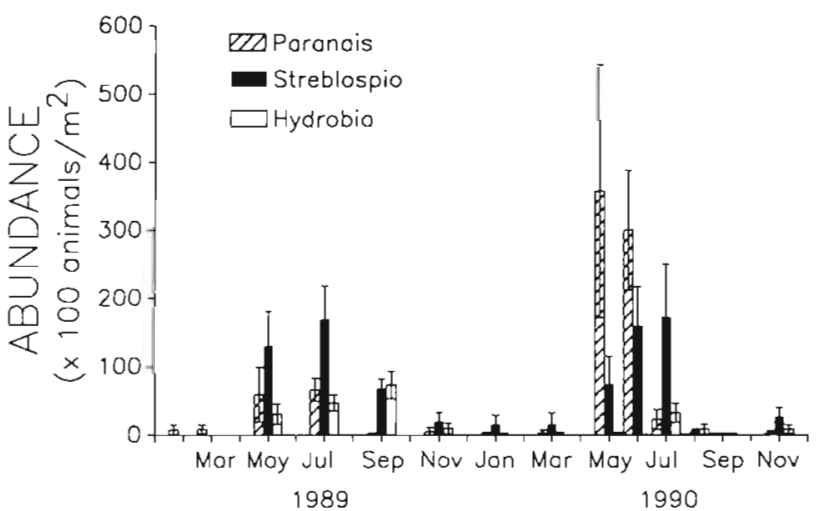

Fig. 1. Paranais litoralis, Streblospio benedicti, Hydrobia truncata. Seasonal variation of population densities of the major surface and near-surface deposit feeders in a mid-intertidal mudflat site at Flax Pond, New York (error bars $=\mathrm{SD}$ )

expansion and fall decline has been observed previously in Flax Pond (S. Stewart unpubl.) and in other salt marsh soft bottoms (Wiltse et al. 1984).

In both years there is a sharp increase in bacteria abundance in spring (Fig. 2), though the increase occurred in May 1989 and March 1990. Peak diatom abundance (Fig. 3), however, occurred in July samples of both years. We did not survey Ulva rotundata abundance during this period, but on this Flax Pond mudflat green seaweeds regularly undergo a cycle such as that depicted in some 1984 data (Fig. 4). Standing stock is low in the mid-intertidal site we sampled for animals, but is higher in the lowest part of the intertidal (at low water spring tide level).

Temperature fluctuates widely through the year (Fig. 5) and surface sediment temperatures may surpass $30^{\circ} \mathrm{C}$. Even at $5 \mathrm{~cm}$ depth, temperatures reach $25^{\circ} \mathrm{C}$.

Fig. 6 shows the results of the field predation experiment for total counts for the polychaete Streblospio benedicti and the oligochaete Paranais litoralis (the 2 most abundant species). At the time of the initiation of

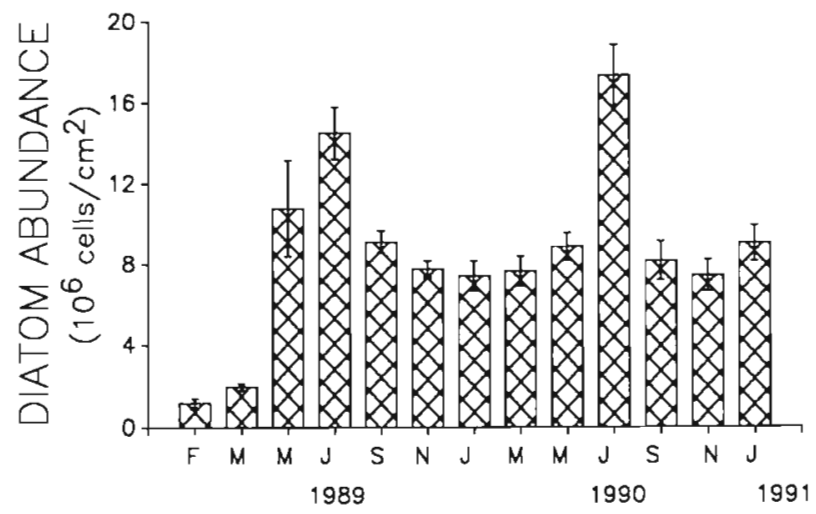

Fig. 3. Seasonal change in diatom abundance in the sediment at the Flax Pond site (error bars = SD)

the field experiment, $P$. litoralis populations were already declining, but $S$, benedicti populations were increasing modestly. Table 1 shows the 3-way ANOVA (mixed model; Cage: fixed treatment; Site and Date: random effects) for the abundances of $P$. litoralis, $S$. benedicti, and the total abundance of the 5 species included in the study. There was no significant difference in abundance in caged vs non-caged samples for P. litoralis. The analysis of $S$. benedicti and total abundances showed significant Cage by Site, Cage by Date, and Site by Date interactions that may hide a significant Cage effect. Thus, the data were analyzed by date as 2 -way ANOVAs. The results (Table 2) showed that for the most part there was no significant effect of cage on abundances (except for the July 21 sample where abundances of $S$. benedictioutside the cages were slightly lower than those inside).

\section{Laboratory bioassay results}

Fig. 7 shows the population change of Paranais litoralis as a function of time (sediment collected March or July

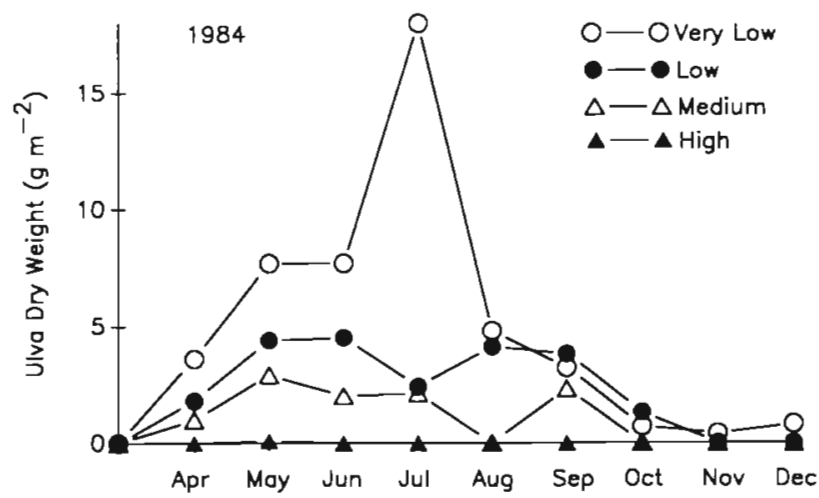

Fig. 4. Ulva rotundata. Seasonal changes in biomass of seaweed at high, mid-intertidal, low, and very low (mean low water spring) levels in the Flax Pond mudflat

Fig. 2. Seasonal change in sediment bacteria abundance at the Flax Pond site (error bars = SD) 


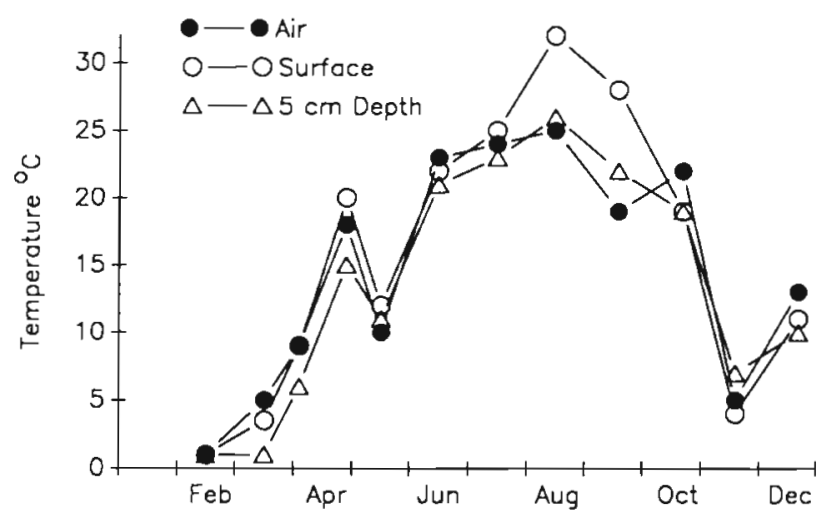

Fig. 5. Seasonal temperature sampling at Flax Pond in air, and at $1 \mathrm{~cm}$ and $5 \mathrm{~cm}$ into the sediment at the mid-intertidal Flax Pond mudflat site

1989) and depth at which sediment was collected in the field below the sediment-water interface. In the March sediment, there is a distinctly greater response of $P$. litoralis to the surface $\mathrm{cm}$ of sediment, where numbers nearly double. At other depths, population size does not increase very much and then declines. A nested analysis of variance of the data at Day 13 shows no significant differences in population growth as a function of sediment core $(F=0.86, \mathrm{p}=0.43)$, so we grouped data by sediment depth and the resulting ANOVA shows a strong effect of the depth treatment $(F=21.65, \mathrm{p}<0.001)$. The surface sediment population level is greater than the other 2 levels (post hoc test, $p<0.001$ ), and the $1-2 \mathrm{~cm}$ layer is somewhat greater than the $2-3 \mathrm{~cm}$ layer (post hoc test, $\mathrm{p}=0.047$ ). In July the response is quite different, since population increase is not significantly different at all sediment levels. The July response, moreover, is not as strong at any level, relative to the surface sediment response in the March sediment. Populations increase to about $50 \%$ over starting levels. A nested ANOVA of the data at Day 12 shows no significant among-core effects $(F=1.399, \mathrm{p}=0.259)$, and a combined core analysis
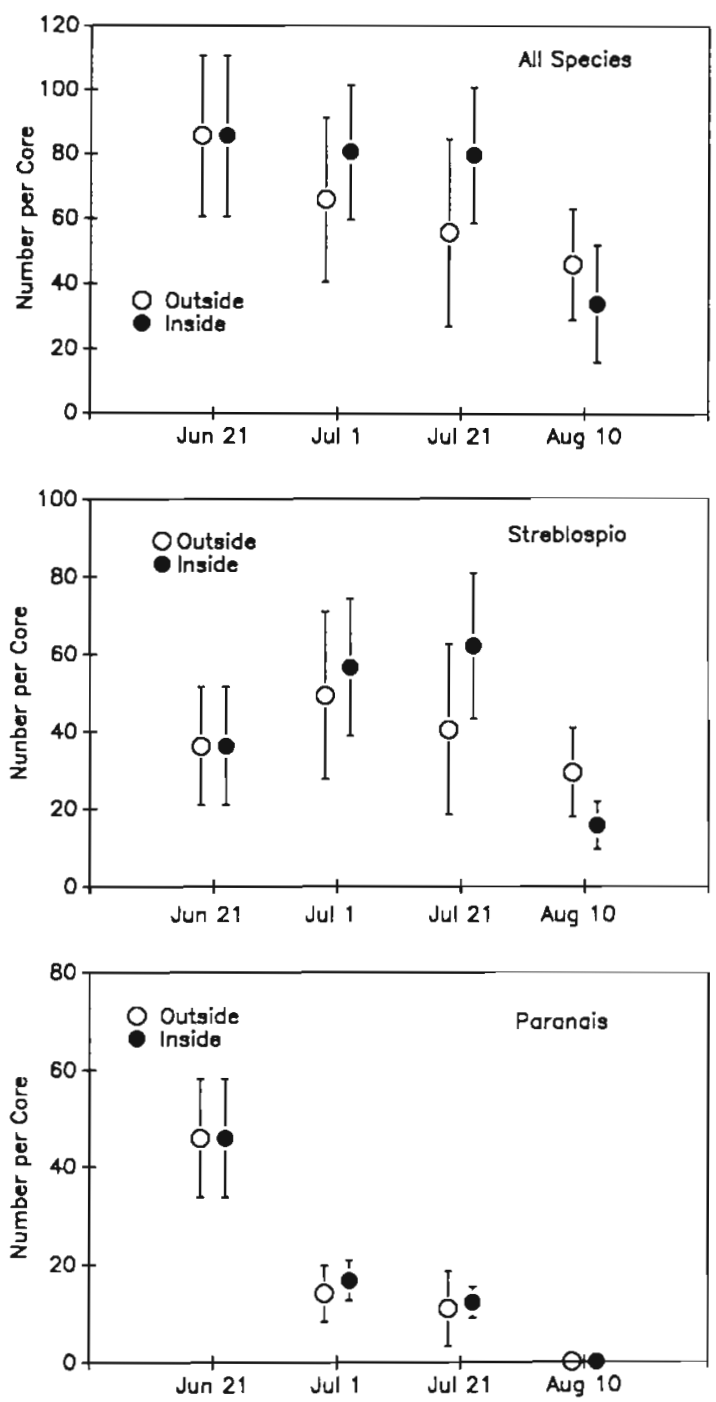

Fig. 6. Gemma gemma, Hydrobia truncata, Streblospio benedicti, Paranais litoralis. Results of the caging/predation field experiment. Top: Changes inside and outside of cages for total abundance. Middle: Changes in S. benedicti. Bottom: Changes in $P$. litoralis (Error bars $=\mathrm{SD}$ )

Table 1. Three-way ANOVAs for the abundances of Paranais litoralis, Streblospio benedicti, and total abundance of the 5 species included ( $P$. litoralis, $S$. benedicti, Gemma gemma, Hydrobia truncata, Ulva rotundata)

\begin{tabular}{|c|c|c|c|c|c|c|c|c|c|}
\hline & \multicolumn{3}{|c|}{ P. Litoralis } & \multicolumn{3}{|c|}{ S. benedicti } & \multicolumn{3}{|c|}{ Total } \\
\hline & $\mathrm{d} \mathbf{f}$ & MS & $F$ & $\mathrm{df}$ & MS & $F$ & $\mathrm{df}$ & MS & $F$ \\
\hline Cage & 1 & 27 & $0.401 \mathrm{~ns}$ & 1 & 375 & $0.216 \mathrm{~ns}$ & 1 & 1170 & $0.478 \mathrm{~ns}$ \\
\hline Site & 1 & 237 & $1.718 \mathrm{~ns}$ & 1 & 5142 & $7.285 \mathrm{~ns}$ & 1 & 7974 & $5.179 \mathrm{~ns}$ \\
\hline Date & 3 & 4386 & $62.58^{\circ}$ & 3 & 3946 & $0.188 \mathrm{~ns}$ & 3 & 6481 & $2.517 \mathrm{~ns}$ \\
\hline Cage $\times$ Site & 1 & 77 & $3.91 \mathrm{~ns}$ & 1 & 187 & $5.8 \mathrm{~ns}$ & 1 & 714 & $42.51^{\circ}$ \\
\hline Cage $\times$ Date & 2 & 9 & $0.46 \mathrm{~ns}$ & 2 & 1584 & $49.11^{\circ}$ & 2 & 1749 & $104.1 \cdots$ \\
\hline Site $\times$ Date & 3 & 81 & $4.09 \mathrm{~ns}$ & 3 & 551 & $17.08^{\circ}$ & 3 & 842 & $50.14^{\circ}$ \\
\hline Cage $\times$ Site $\times$ Date & 2 & 20 & $0.62 \mathrm{~ns}$ & 2 & 32 & $0.17 \mathrm{~ns}$ & 2 & 17 & $0.05 \mathrm{~ns}$ \\
\hline
\end{tabular}


Table 2. Two-way ANOVAs (by Date) for Streblospio benedicti abundance and total abundance of the 5 species included in the study ( $S$. benedicti, Paranais litoralis, Gemma gemma, Hydrobia truncata, Ulva rotundata)

\begin{tabular}{|c|c|c|c|c|c|c|c|c|c|}
\hline & \multicolumn{3}{|c|}{ Cage } & \multicolumn{3}{|c|}{ Site } & \multicolumn{3}{|c|}{ Cage $\times$ Site } \\
\hline & $\mathrm{df}$ & MS & $F$ & $\mathrm{df}$ & MS & $F$ & $\mathrm{df}$ & MS & $F$ \\
\hline \multicolumn{10}{|c|}{ S. benedicti } \\
\hline Jun 21 & - & - & - & 1 & 348 & $1.57 \mathrm{~ns}$ & - & - & - \\
\hline Jul 1 & 1 & 259 & $2.07 \mathrm{~ns}$ & 1 & 3125 & $13.16^{\cdots}$ & 1 & 125 & $0.53 \mathrm{~ns}$ \\
\hline Jul 21 & 1 & 2332 & $12.96^{\circ}$ & 1 & 3808 & $16.26^{\cdots} \cdot$ & 1 & 1.8 & $0.01 \mathrm{~ns}$ \\
\hline Aug 10 & 1 & 952 & $7.62 \mathrm{~ns}$ & 1 & 168 & $2.14 \mathrm{~ns}$ & 1 & 125 & $1.59 \mathrm{~ns}$ \\
\hline \multicolumn{10}{|l|}{ Total } \\
\hline Jun 21 & - & - & - & 1 & 1000 & $1.74 \mathrm{~ns}$ & - & - & - \\
\hline Jul 1 & 1 & 1080 & $5.11 \mathrm{~ns}$ & 1 & 3836 & $10.79 \cdots$ & 1 & 211 & $0.59 \mathrm{~ns}$ \\
\hline Jul 21 & 1 & 2856 & 20.33 ns & 1 & 6516 & $21.37^{\cdots} \cdot$ & 1 & 140 & $0.46 \mathrm{~ns}$ \\
\hline Aug 10 & 1 & 732 & $1.85 \mathrm{~ns}$ & 1 & 211 & $0.69 \mathrm{~ns}$ & 1 & 396 & $1.29 \mathrm{~ns}$ \\
\hline
\end{tabular}

shows no significant depth effects $(F=0.663, \mathrm{p}=0.52)$. The July sediment populations, moreover, decline to zero by Day 18 whereas the March sediment populations do not disappear until Day 27.
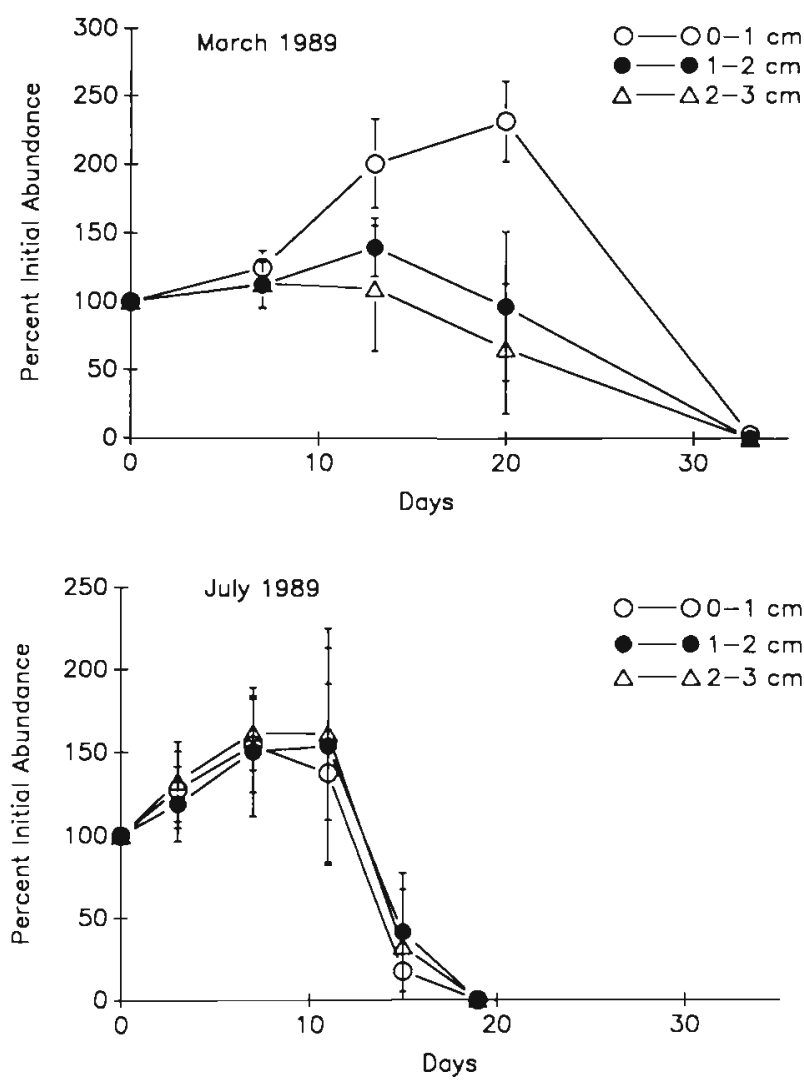

Fig. 7. Paranais litoralis. Results of the sediment depthresponse experiment. Relative population growth of worms on sediments collected from different depths below the sediment-water interface and separated into dishes. Top: Population change on sediment collected in March 1989. Bottom: Population change on July 1989 sediment. (Error bars = SD)
The seasonal surface sediment results for 1989 and 1990 are presented in Fig. 8. For the 1989 experiment there is significant heterogeneity among months (ANOVA: $F=16.0, p<0.001$ ) but no among-tank effect ( $F=0.525$, ns). In 1989 , population response steadily increases from February to July surface sediments, but then declines precipitously in fall sediments, with a
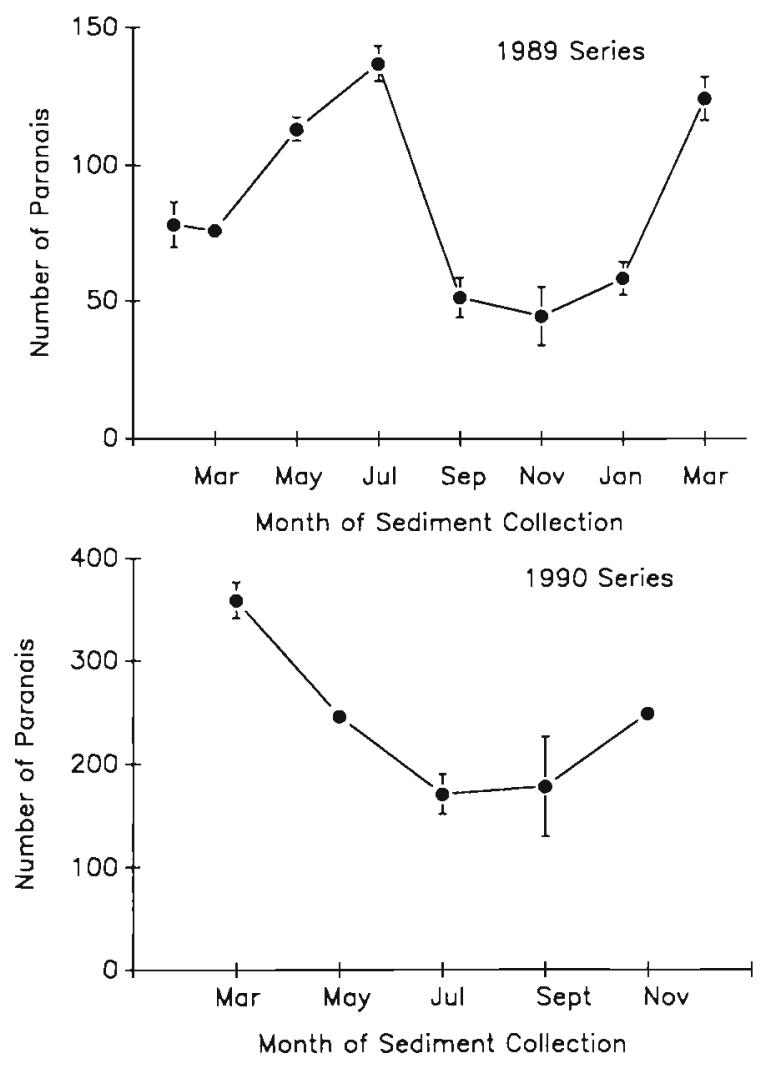

Fig. 8. Paranais litoralis. Seasonal response experiment. Abundance of worms when exposed to sediments collected in different months. Top: Data for 1989 seasonal samples. Bottom: Data for 1990 series. (Error bars $=\mathrm{SE}$ ) 
steady increase in winter-early spring sediments. Worms in the September sediments looked relatively thin and small in size, though we have no systematic measurements (see Levinton \& Stewart 1982). There is also significant among-month heterogeneity for the 1990 series $(F=9.1, \mathrm{p}=0.001)$. Population response steadily declines from March to September surface sediments, but then increases in November. Here, too, worms raised in September sediments appeared to be unhealthy, as judged by their size.

Fig. 9 shows the results of the temperature $x$ season temperature population response experiment. As expected from other results, the May sediments promoted far more population growth than the September sediments. High temperature also exerts a negative effect on populations growing on both May and September sediments. A 2-way ANOVA demonstrates significant differences for both month of sediment collection $(F=7.9, \mathrm{p}=0.018)$ and temperature $(F=$ $41.1, p<0.001)$, but no significant interaction effect between sediment and temperature ( $F=0.095$, ns).

Fig. 10 illustrates the organic matter retention in the 1989 and 1990 seasonal surface sediments. In both cases, organic matter retention declines steadily from winter to fall sediments (ANOVA on linear regression, $p<0.05$ in both cases). In both cases, organic matter retention declines from ca $30 \%$ to ca $20 \%$ during this period, suggesting that organics in fall sediments are more difficult to digest.

\section{DISCUSSION}

At Flax Pond, surface deposit feeding invertebrates recruit rapidly in May and June and then decline in early summer. In a previous study at Flax Pond a fall

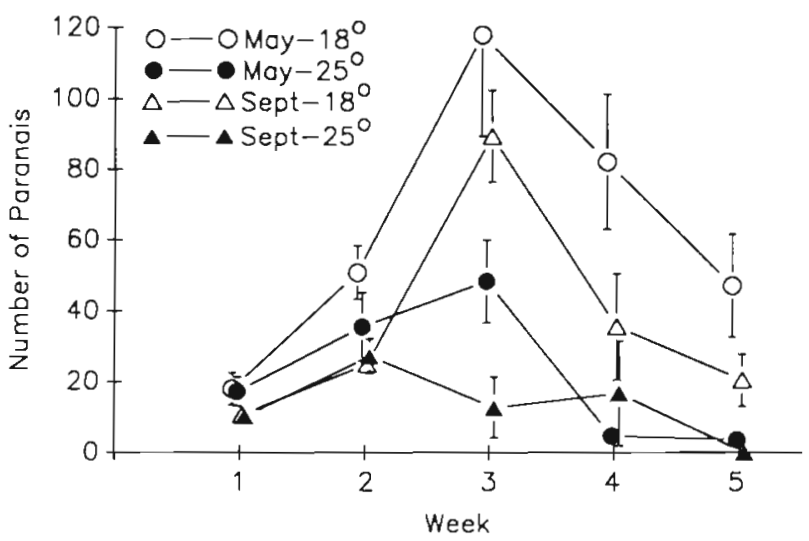

Fig. 9. Paranais litoralis. Temperature $\times$ seasonal response experiment. Population growth of worms on May 1989 and September 1989 surface sediments at 18 and $25^{\circ} \mathrm{C}$. (Error bars $=\mathrm{SE})$
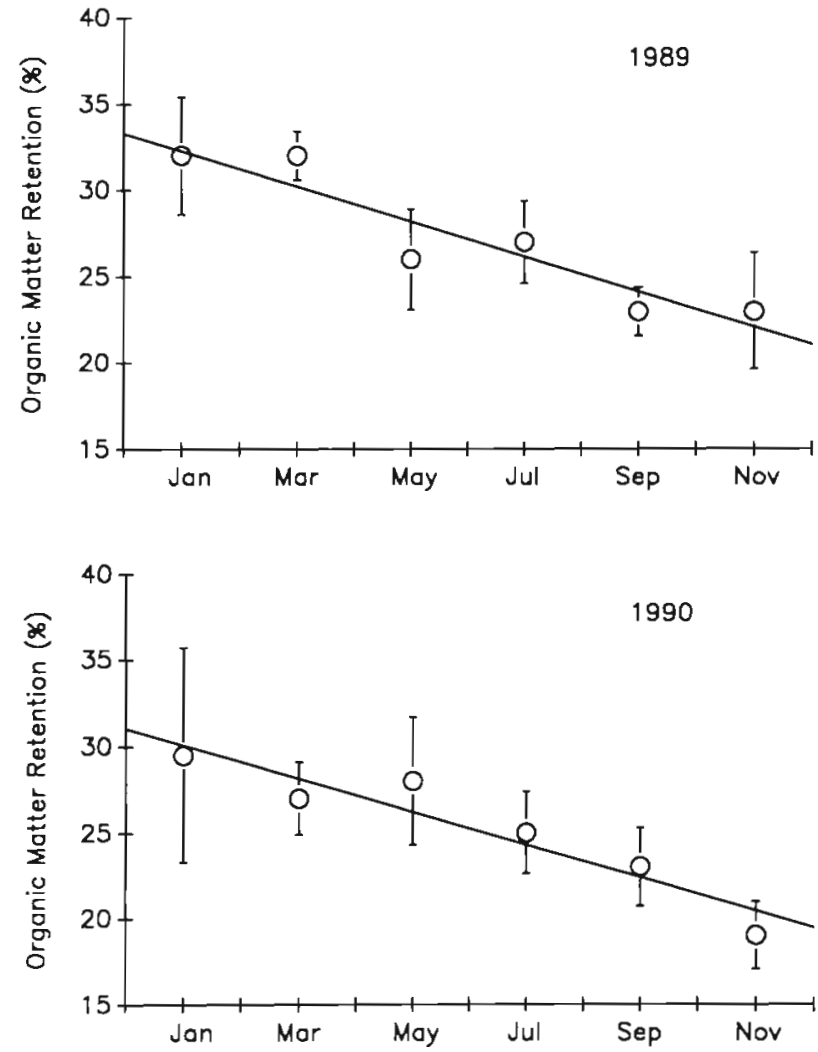

Fig. 10. Paranais Itoralis. Organic matter retention by worms on surface sediments collected in different months. Top: 1989 series. Bottom: 1990 series. (Error bars $=\mathrm{SE}$ )

population burst of Paranais litoralis was found (S. Stewart unpubl.). Our field caging studies suggest that predation is not necessary to explain the late summer decline, as has been found in some other mudflats (Reise 1975, Schneider 1978) and tidal creeks (Wiltse et al. 1984). Calculations by Marsh \& Tenore (1990) similarly failed to identify predation as the major factor explaining summer population declines in mesohaline sites in Chesapeake Bay.

Our results on sediment nutritional value suggest strong seasonal heterogeneity in the nutritional value of sediment. Spring or early summer sediments seem to promote deposit feeder growth far more effectively than fall sediments. Our results are consistent with those of Marsh et al. (1989) who found that summer detritus was a poorer nutritional source than spring detritus for Capitella capitata. From laboratory studies, it appears that levels of essential fatty acids and amino acids may have been too low to support $C$. capitata growth. Our results, however, are based directly on the sediments within which the deposit feeders live and feed. As Tenore et al. (1982) note, detritus, especially that derived from seaweeds, is nutritionally rich, but it may be also consumed by bacteria. It is therefore 
insufficient to merely assay the nutritional value of sedimenting detritus to deposit feeders. One must examine the sediment into which the detritus is incorporated as done in this study.

Our population growth assays show, furthermore, some limited evidence for an increase of nutritional value of the sediments in the late fall, as supported by increased Paranais litoralis population growth. In the field growth may be precluded owing to low temperature. The fall increase in nutritional value may be due to the following: (1) fall and winter deposition of particulate organic matter; (2) steady decomposition (or decomposition exceeding loss from feeding by deposit feeders), yielding more nutritionally valuable substances in fall and winter. Carey \& Mayer (1990) presented evidence that decomposition yields nutritionally valuable food sources for deposit feeders, at least when nitrogen and carbon are considered. The organic matter retention data are consistent with the hypothesis that nutritional value of the sediment is declining from spring to fall.

The laboratory population growth response to frozen sediments differed between the 2 years, since growth declines between July and September in the 1989 data, but declines after March in the 1990 samples. The cause of this is not clear, but it may be related to detrital deposition events which were not recorded. Our qualitative observations of the marsh suggest that deposition of detritus is very patchy both qualitatively and quantitatively. In some years, large quantities of the green seaweed Ulva rotundata are transported to the upper intertidal zone, whereas in other years the upper intertidal may be covered by decaying Spartina alterniflora. Unfortunately, the spatial patterns of detrital sources and deposition have not been investigated, except to identify the ultimate source, using isotopic tracers (Peterson et al. 1986). Levinton \& McCartney (1991) have recently developed a photosynthetic pigment tracer method to detect spatial changes in seaweed detrital deposition and this might be used in future studies to detect deposition events. A past fall explosion of Paranais litoralis could be related to a sudden deposition of large amounts of $S$. alterniflora detritus at the Flax Pond site in 1983 (S. Stewart unpubl. obs.). In subtidal shallow water sites, phytodetritus is probably the main source of deposition (see Levinton 1989)

The sediment-depth experiment suggests that surface sediments are nutritionally enriched in late winter, and that this relative enrichment disappears by the end of summer. This result conforms to previous findings, which demonstrate that spring deposition of phytodetritus is a major subsidy of the benthos (Elmgren 1984, Levinton 1989, Marsh \& Tenore 1990). The change may partially be due to spring and summer degradation of nutritionally rich material previously deposited on the surface in winter, followed by some bioturbation in early summer, which would tend to homogenize the sediment vertically. If the latter process occurs, it is important to remember that most of the animals in this mud flat are found in the upper $1 \mathrm{~cm}$ of mud and do not have access to much of the nutritional value of the sediment, since the anoxic zone is so shallow (less than $1 \mathrm{~cm}$ in Flax Pond). In either case, the food available to these deposit feeders declines in September. This pattern has also been observed for particulate organic matter available to suspension feeders in Long Island Sound (G. R. Lopez pers. comm.). Marsh et al. (1989) demonstrated that detritus collected in sediment traps in the spring sustained somatic growth of juveniles of the polychaete Capitella sp. 1, but worms did not grow on summer detritus.

While both the population growth and organic matter retention assays showed declines of sediment quality, the assays were not consistent. The population assay showed sharp changes, whereas the organic matter retention assays showed gradual reduction of absorption efficiency as the season progressed. There were inconsistencies, however. For example, the population growth increased from March to May 1989, but the organic matter retention decreased (Figs. 8 \& 10). The magnitude and degree of decline of organic matter retention were similar between years. The difference may imply that the population growth and organic matter retention measures may be assessing completely different responses. The simplest hypothesis would argue that the radiocarbon labeled a biased fraction of the nutritionally significant organic matter. If so, then the technique is not very useful, since we have no idea as to the extent to which organic matter was labeled in the experiment. It is also possible that carbon retention, while declining through the season, may not be the limiting factor in population growth. Nitrogen, specific amino acids, or essential fatty acids may be crucial (e.g. Rice 1982, Marsh et al. 1989).

The bioassay approach is necessary since it is difficult to characterize the sediment in nutritionally meaningful terms, that can be translated into a prediction of secondary production (Levinton \& Stewart 1988). The large amount of organic matter found in sediments is in varying states of degradation and much of it is not readily available for assimilation by deposit feeders (Rice 1982). Bioassays such as population growth and organic matter retention give a direct idea of the changing nutritive state of the sediment. Such a bioassay approach might be readily applied to the deep sea, where it is of interest to know whether seasonal supplies have a nutritive impact on the sediment (e.g. 
Carney 1989). Of course, species choice in any bioassay is critical to understanding sediment quality changes. It would also be very useful to be able to employ more nutritionally relevant measures, such as essential amino acids and fatty acids, and apply them quantitatively to a prediction of population growth.

Our results suggest an approach to sediment food quality that complements other attempts to develop measures of the nutritional value of the sediment, which thus far cannot easily predict what is good for the deposit feeders (e.g. Mayer 1989, Cheng \& Lopez 1991). Unfortunately, there still is a gap between laboratory experiments using defined foods, which permit calculations of the minimum daily rations for essential amino acids and some fatty acids (e.g. Tenore \& Chesney 1985, Marsh et al. 1989), and our knowledge of the nutritional value of the sediment. Our approach has the advantage of assessing directly the potential food quality of the sediment, but has the disadvantage of not quantifying what in the sediment is actually changing and affecting the animals differentially, nor does it point to a specific mechanism of temporal increase in nutritional value. It is obvious that both approaches are needed to provide a complete picture of food supply and limitation to deposit feeder populations.

Acknowledgements. This study was supported by a National Science Foundation grant to J.S.L. We thank Steve Stewart, Yuki Yamamoto, and many others who helped with field and laboratory work. We are grateful to Michael Judge for his criticisms of the manuscript, and are also especially grateful to Don Rice and 3 anonymous reviewers. Contribution no. 857 to the Program in Ecology and Evolution, State University of New York at Stony Brook.

\section{LITERATURE CITED}

Bayne, B. L., Widdows, J., Thompson, R. J. (1976). Physiological integrations. In: Bayne, B. L. (ed.) Marine mussels: their ecology and physiology. Cambridge Univ. Press, Cambridge, p. 261-291

Bell, S. S., Coull, B. C. (1978). Field evidence that shrimp predation regulates meiofauna. Oecologia 35: 141-148

Calow, P., Fletcher, C. R. (1972). A new radiotracer technique involving ${ }^{14} \mathrm{C}$ and ${ }^{51} \mathrm{Cr}$ for estimating the assimilation efficiency of aquatic primary producers. Oecologia 9: $155-170$

Cammen, L. M. (1980). The significance of microbal carbon in the nutrition of the deposit feeding polychaete Nereis succinea. Mar. Biol 61: 9-20

Cammen, L. M. (1989). The relationship between ingestion rate of deposit feeders and sediment nutritional value. In: Lopez, G. R., Taghon, G. L., Levinton, J. S. (eds.) Ecology of marine deposit feeders. Springer-Verlag, New York, p. 201-222

Carey, D. A., Mayer, L. M. (1990). Nutrient uptake by a deposit-feeding enteropneust: nitrogenous sources. Mar. Ecol. Prog. Ser. 63: 79-84
Carney, R. S. (1989). Examining relationships between organic carbon flux and deep-sea deposit feeding. In: Lopez, G. R., Taghon, G. L., Levinton, J. S. (eds.) Ecology of marine deposit feeders. Springer-Verlag, New York, p. $24-58$

Cheng, I.-J., Lopez, G. R. (1991). Contributions of bacteria and sedimentary organic matter to the diet of Nucula proxima, a deposit-feeding protobranchiate bivalve. Ophelia 34: $157-170$

Chesney, E. J., Tenore, K. R. (1985). Oscillations of laboratory populations of the polychaete Capitella capitata (Type I): their cause and implications for natural populations. Mar. Ecol. Prog. Ser. 20: 289-296

Christensen, H., Kanneworf, E. (1985). Sedimenting phytoplankton as a major food source for suspension and deposit feeders in the Oresund. Ophelia 24: 223-224

Elmgren, R. (1984). Trophic dynamics in the enclosed, brackish Baltic Sea. Rapp. P.-v. Réun. Cons. int. Explor Mer 183: 152-169

Fenchel, T. (1970). Studies on the decomposition of organic detritus derived from the turtle grass Thalassia testudinum. Limnol. Oceanogr. 15: 14-20

Fenchel, T., Kofoed, L. H. (1976). Evidence for exploitative interspecific competition in mud snails (Hydrobiidae). Oikos 27: $367-376$

George, J. D. (1964). Organic matter available to the polychaete Cirriformia tentaculata (Montagu) living in an intertidal mud flat. Limnol. Oceanogr. 9: 453-455

Hargrave, B. T (1970). The utilization of benthic microflora by Hyalella azteca. J. Anim. Ecol. 39: 427-437

Harrison, P. G., Mann, K. H. (1975). Detritus formation from eelgrass (Zostera marina L.): the relative effects of fragmentation, leaching and decay. Limnol. Oceanogr. 20 : $924-934$

Hobbie, J. E., Daley, R. J., Jasper, S. (1977). The use of Nuclepore filters for counting bacteria by fluorescence microscopy. Appl. environ. Microbiol. 33: 1225-1228

Jumars, P. A., Penry, D. L. (1989). Digestion theory applied to deposit feeding. In: Lopez, G. R., Taghon, G. L., Levinton, J. S. (eds.) Ecology of marine deposit feeders. SpringerVerlag. New York, p. 114-128

Juniper, S. K. (1987a). Deposit feeding ecology of Amphibola crenata 1. Long-term effects of deposit feeding on sediment micro-organisms. N.Z. J. mar. Freshwat. Res. 21: $235-246$

Juniper, S. K. (1987b). Deposit feeding ecology of Amphibola crenata. II. Contribution of microbial carbon to Amphibola's carbon requirements. N.Z. J. mar. Freshwat. Res. 21: $247-251$

Kemp, P. (1986). Direct uptake of detrital carbon by the deposit-feeding polychaete Euzonus mucronata (Treadwell). J. exp. mar. Biol. Ecol. 99: 49-61

Kofoed, L., Forbes, V., Lopez, G. R. (1989). Time-dependent absorption in deposit feeders. In: Lopez, G. R., Taghon, G. L., Levinton, J. S. (eds.) Ecology of marine deposit feeders. Springer-Verlag, New York, p. 129-148

Levin, L. A. (1986). The influence of tides on larval availability in shallow waters overlying a mudflat. Bull. mar. Sci. 39: $224-233$

Levinton, J. (1977). The ecology of deposit-feeding communities: Quisset Harbor, Massachusetts. In: Coull, B. C. (ed.) Ecology of marine benthos. Univ. of South Carolina, Columbia, p. 191-228

Levinton, J. S. (1979). The effect of density on deposit-feeding populations: movement, feeding and floating of Hydrobia ventrosa Montagu (Gastropoda: Prosobranchia). Oecologia 43: $27-39$ 
Levinton, J. S. (1980). Particle feeding by deposit feeders: models, data, and a prospectus. In: Tenore, K. R., Coull, B. C. (eds.) Marine benthic dynamics. University of South Carolina, Columbia, p. 423-429

Levinton, J S. (1983). The latitudinal compensation hypothesis: growth data and a model of latitudinal growth differentiation based upon energy budgets. I. Interspecific comparison of Ophryotrocha (Polychaeta: Dorvilleidae) Biol. Bull. 165: 686-698

Levinton, J. S. (1989). Deposit feeding and coastal oceanography. In: Lopez, G. R., Taghon, G. L., Levinton, J. S. (eds.) Ecology of marine deposit feeders. Springer-Verlag, New York, p. 1-23

Levinton, J. S., Bianchi, T. S. (1981). Nutrition and food limitation of deposit-feeders. 1. The role of microbes in the growth of mud snails. J. mar. Res. 39: 531-545

Levinton, J. S., McCartney, M. (1991). The use of photosynthetic pigments in sediments as a tracer for sources and fates of macrophyte organic matter. Mar. Ecol. Prog. Ser, 78: 87-96

Levinton, J. S., Stewart, S. (1982). Marine succession: the effect of two deposit-feeding gastropod species on the population growth of Paranais Litoralis Müller 1784 (Oligochaeta). J. exp. mar. biol. ecol. 59: 231-241

Levinton, J. S., Stewart, S. (1988). Effects of sediment organics, detrital input, and temperature on demography. production, and body size of a deposit feeder. Mar. Ecol. Prog. Ser. 49: 259-266

Levinton, J. S., Stewart, S., Dewitt, T H. (1985). Field and laboratory experiments on interference between Hydrobja totteni and llyanassa obsoleta (Gastropoda) and its possible relation to seasonal shifts in vertical mudflat zonation. Mar. Ecol. Prog. Ser. 22: 53-58

Lonsdale, D. J., Levinton, J. S. (1985). Latitudinal differentiation in copepod growth: an adaptation to temperature. Ecology 66: 1397--1407

Lopez, G. R., Cheng, I.-J. (1983). Synoptic measurements of ingestion rate, ingestion selectivity, and absorption efficiency of natural foods in the deposit-feeding molluscs Nucula annulata (Bivalvia) and Hydrobia totteni (Gastropoda). Mar. Ecol. Prog. Ser. 11:55-62

Lopez, G. R., Crenshaw, M. A. (1982). Radiolabelling of sedimentary organic matter with ${ }^{14} \mathrm{C}$-formaldehyde: preliminary evaluation of a new technique for use in depositfeeding studies. Mar. Ecol. Prog. Ser. 8: 283-289

Lopez, G. R., Levinton, J. S. (1987). Ecology of deposit-feeding animals in marine sediments. Q. Rev. Biol. 62: 235-260

Marsh, A. G., Grémare, A., Tenore, K. R. (1989). Effect of food type and ration on growth of juvenile Capitella sp. 1 (Annelida: Polychaeta): macro- and micronutrients Mar. Biol. 102: 519-527

Marsh, A. G., Tenore, K. R. (1990). The role of nutrition in regulating the population dynamics of opportunistic, surface deposit feeders in a mesohaline community. Limnol. Oceanogr. 35: 710-724

Mayer, L. M. (1989). The nature and determination of nonliving sedimentary organic matter as a food source for deposit feeders. In: Lopez, G. R., Taghon, G. L., Levinton, J.S. (eds.) The ecology of marine deposit feeders. SpringerVerlag, New York, p. 98-113

Mayer, L. M., Schick, L. L., Setchell, F. W. (1986). Measurement of protein in nearshore marine sediments. Mar. Ecol. Prog. Ser. 30: 159-165

Morrisey, D.J. (1987). Effect of population density and presence of a potential competitor on the growth rate of the mud snail Hydrobia ulvae (Pennant). J. exp. mar. Biol. Ecol. 108: 275-295

This article was presented by K. R. Tenore, Solomons, Maryland, USA
Morrisey, D. J. (1988). Differences in effects of grazing by deposit-feeders Hydrobia ulvae Pennant (Gastropoda: Prosobranchia) and Corophium arenarium Crawford (Amphipoda) on sedimentary microalgal population. 1. Qualitative effects. J. exp. mar. Biol. Ecol. 118: 33-42

Newell, R. C. (1965). The role of detritus in the nutrition of two marine deposit feeders, the prosobranch Hydrobia ulvae and the bivalve Macoma balthica. Proc. zool. Soc. Lond. 144: $25-45$

Pace, M. L., Shimmel, S., Darley, W. M. (1979). The effect of grazing by a gastropod, Nassarius obsoletus, on the benthic microbial community of a saltmarsh mudflat. Estuar. coast. mar. Sci. 9: 121-134

Penry, D. L., Jumars, P. A. (1987). Modeling animal guts as chemical reactors. Am. Nat. 129: 69-96

Penry, D. L., Jumars, P. A. (1990). Gut architecture, digestive constraints and feeding ecology of deposit-feeding and carnivorous polychaetes. Oecologia 82: 1-11

Peterson, B. J., Howarth, R. W., Garritt, R. H. (1986). Sulfur and carbon isotopes as tracers of salt-marsh organic matter flow. Ecology 67: 865-874

Peterson, C. H., Andre, S. V. (1980). An experimental analysis of interspecific competition among marine filter feeders in a soft-sediment environment. Ecology 61: 129-139

Reise, K. (1985). Tidal flat ecology: an experimental approach to species interactions. Springer-Verlag, Berlin

Rice, D. L. (1982). The detritus nitrogen problem: new observations and perspectives from organic geochemistry. Mar. Ecol. Prog. Ser 9: 153-162

Rice, D. L., Rhoads, D. C. (1989). Early diagenesis of organic matter and the nutritional value of sediment. In: Lopez, G. R., Taghon, G. L., Levinton, J. S. (eds.) Ecology of marine deposit feeders. Springer-Verlag, New York, p. 59-97

Schneider, D. C. (1978). Equalisation of prey numbers by migratory shorebirds. Nature 271: 353-354

Smith, L. D., Coull, B. C. (1987). Juvenile spot (Pisces) and grass shrimp predation on meiobenthos in muddy and sandy substrata. J. exp. mar. Biol. Ecol. 105: 123-136

Taghon, G. L. (1981). Beyond selection: optimal ingestion rate as a function of food value. Am. Nat. 118: 202-214

Tenore, K. R. (1977). Growth of Capitella capitata cultured on various levels of detritus derived from different sources. Limnol Oceanogr. 22: 936-941

Tenore, K. R., Cammen, L., Findlay, S. E. G., Phillips, N. (1982). Perspectives of research on detritus: do factors controlling the availability of detritus to macroconsumers depend on its source? J. mar. Res. 40: 473-490

Tenore, K. R., Chesney (1985). The effects of interaction of rate of food supply and population density on the bioenergetics of the opportunistic polychaete, Capitella capitata (type 1). Limnol. Oceanogr. 30: 1188-1195

Tunnicliffe, V. J., Risk, M. J. (1977). Relationships between Macoma balthica and bacteria in intertidal sediments: Minas Basin, Bay of Fundy. J. mar. Res. 35: 499-507

Wiltse, W. I., Foreman, K. H., Teal, J. M., Valiela, I. (1984). Effects of predators and food resources on the macrobenthos of salt marsh creeks. J. mar. Res. 42: 923-942

Woodin, S. A. (1974). Polychaete abundance patterns in a marine soft-sediment environment: the importance of biological interactions. Ecol. Monogr. 44: 171-187

Woodin, S. A. (1976). Adult-larval interactions in dense infaunal assemblages: patterns of abundance. J. mar. Res. 34 : 25-41

Yingst, J. Y (1976). The utilization of organic matter in shallow marine sediments by an epibenthic depositfeeding holothurian. J. exp. mar. Biol. Ecol. 23: 55-69

Manuscript first received: October 10, 1991

Revised version accepted: December 31, 1992 